\title{
EXISTENCE OF SOLUTIONS FOR A CLASS OF FRACTIONAL HAMILTONIAN SYSTEMS WITH IMPULSIVE EFFECTS
}

\author{
JiANWEN ZHOU, YANNING WANG AND YONGKUN LI
}

\begin{abstract}
In this paper, we are concerned with a class of fractional Hamiltonian systems containing right Riemann-Liouville fractional derivatives and left Caputo fractional derivatives with impulsive effects. Under certain conditions, the existence of solutions are obtained for this class of systems by means of the least action principle, the saddle point theorem as well as some skills of inequalities. One of the innovations of this paper is that the variational functional of these problems are established in a proper fractional derivative space. Moreover, in order to show the feasibility and effectiveness of our results, we present two examples.
\end{abstract}

Mathematics subject classification (2010): 34B37, 34K37, 34K45, 49J40.

Keywords and phrases: Fractional Hamiltonian systems, impulses, variational approach, critical point theorem.

\section{REFERENCES}

[1] J. Mawhin, M. Willem, Critical Point Theory and Hamiltonian Systems, Springer-Verlag, Berlin, 1989.

[2] J. W. ZHOU, Y. K. LI, Existence of solutions for a class of second-order Hamiltonian systems with impulsive effects, Nonlinear Anal. 72, (2010) 1594-1603.

[3] W. G. Glockle, T. F. Nonnenmacher, A fractional calculus approach of self-similar protein dynamics, Biophys. J. 68, (1995) 46-53.

[4] F. MAINARd, Fractional calculus: Some basic problems in continuum and statistical mechanics, Springer-Verlag, Wien, 1997.

[5] K. DieThelm, A. D. FREed, On the solution of nonlinear fractional order differential equations used in the modeling of viscoelasticity, Scientific Computing in Chemical Engineering II, (1999) 217-224.

[6] R. Hilfer, Applications of Fractional Calculus in Physics, World Scientific, Singapore, 2000.

[7] J. W. KirChNER, X. FENG, C. NEAL, Fractal streamchemistry and its implications for contaminant transport in catchments, Nature 403, (2000) 524-526.

[8] J. Vasundhara Devi, V. Lakshmikantham, Nonsmooth analysis and fractional differential equations, Nonlinear Anal. 70, (2009) 4151-4157.

[9] Y. L. ZHAO, H. B. CHEN, C. J. XU, Nontrivial solutions for impulsive fractional differential equations via Morse theory, Appl. Math. Comput. 307, (2017) 170-179.

[10] Y. ZHou, B. Ahmad, A. ALsAed, Existence of nonoscillatory solutions for fractional neutral differential equations, Appl. Math. Lett. 72, (2017) 70-74.

[11] K. H. ZHAO, Impulsive boundary value problems for two Classes of fractional differential equation with two different Caputo fractional derivatives, Mediterr. J. Math. 13, 3 (2016) 1033-1050.

[12] A. A. Kilbas, H. M. SRivastava, J. J. Trujillo, Theory and applications of fractional differential equations, in: North-Holland Mathematics Studies 204, Elsevier Science, Amsterdam, 2006.

[13] I. Podlubny, Fractional Differential Equations, Academic Press, New York, 1993.

[14] Y. ZHOU, Basic Theory of Fractional Differential Equations, World Scientific, Singapore, 2014.

[15] H. SHI, H. CHEN, Multiplicity results for a class of boundary value problems with impulsive effects, Math. Nachr. 289 (2016) 718-726.

[16] H. SHI, H. CHEN, H. LiU, Morse theory and local linking for a class of boundary value problems with impulsive effects, J. Appl. Math. Comput. 51 (2016) 353-365. 
[17] Y. L. ZHAO, H. B. CHEN, C. J. XU, Nontrivial solutions for impulsive fractional differential equations via Morse theory, Appl. Math. Compput. 307 (2017) 170-179.

[18] T. S. Aleroev, H. T. Aleroeva, J. F. Huang, M. V. Tamm, Y. F. Tang, Y. Zhao, Boundary value problems of fractional Fokker-Planck equations, Compt. Math. Appl. 73, (2017) 959-969.

[19] Y. J. LIU, S. P. CHEN, L. M. OU, Solvability of Sturm-Liouville boundary value problems for multiple order fractional differential equations, Arab J. Math. Sci. 22, (2016) 207-231.

[20] Y. J. CUI, Uniqueness of solution for boundary value problems for fractional differential equations, Appl. Math. Lett. 51 (2016) 48-54.

[21] L. Peng, Y. ZHOU, Bifurcation from interval and positive solutions of the three-point boundary value problem for fractional differential equations, Appl. Math. Comput. 257, (2015) 458-466.

[22] V. Lakshmikantham, D. Bainov, P. Simeonov, Impulsive Differential Equations and Inclusions, World Scientific, Singapore (1989).

[23] E. Ait Dads, M. Benchohra, S. Hamani, Impulsive fractional differential inclusions involving fractional derivative, Fract. Calc. Appl. Anal. 12, (2009) 15-38.

[24] T. D. KE, D. LAN, Decay integral solutions for a class of impulsive fractional differential equations in Banach spaces, Fract. Calc. Appl. Anal. 17, (2014) 96-121.

[25] S. Q. ZHANG, Existence of a solution for the fractional differential equation with nonlinear boundary conditions, Comput. Math. Appl. 61, (2011) 1202-1208.

[26] Y. G. ZhaO, S. R. Sun, Z. L. Han, Q. P. LI, The existence of multiple positive solutions for boundary value problems of nonlinear fractional differential equations, Commun. Nonlinear Sci. Numer. Simul. 16, (2011) 2086-2097.

[27] K. H. Zhao, P. Gong, Positive solutions of Riemann-Stieltjes integral boundary problems for the nonlinear coupling system involving fractional-order differential, Adv. Difference Equ. 2014, 2014:254.

[28] N. Kosmatov, A boundary value problem of fractional order at resonance, Electron. J. Differ. Equ. 135, (2010) 1-10.

[29] W. H. JIANG, The existence of solutions for boundary value problems of fractional differential equations at resonance, Nonlinear Anal. 74, (2011) 1987-1994.

[30] F. JIAO, Y. ZHOU, Existence of solutions for a class of fractional boundary value problems via critical point theory, Comput. Math. Appl. 62, (2011) 1181-1199.

[31] G. BONANNO, R. RODRÍGUEZ-LóPEZ, S. TERSIAN, Existence of solutions to boundary value problem for impulsive fractional differential equations, Fract. Calc. Appl. Anal. 17, (2014) 717-744.

[32] A. A. Kilbas, H. M. Srivastava, J. J. Trujillo, Theory and applications of fractional differential equations, North-Holland Mathematics Studies, vol. 204, Elsevier Science B. V., Amsterdam, 2006.

[33] I. Podlubny, Fractional Differential Equations, Mathematics in Science and Engineering, vol. 198, Academic Press, San Diego, Calif, USA, 1999. 